\title{
Diel variation of chlorophyll $a$ as evidenced from a 13-day station in the equatorial Atlantic Ocean
}

\author{
A. Le Bouteiller, A. Herbland \\ Antenne ORSTOM, Centre Océanologique de Bretagne, BP n 337, 29273 Brest cedex, \\ France.
}

Receveid $17 / 2 / 82$, in revised form $13 / 4 / 82$, accepted $30 / 4 / 82$.

\section{ABSTRACT}

During a 13-day-long study in a fixed position in the Equatorial Atlantic Ocean, the vertical distribution of chlorophyll $a$ was determined by fluorometry in acetone extracts four times a day $(2 \mathrm{~h} 00,8 \mathrm{~h} 00,14 \mathrm{~h} 00$ and $20 \mathrm{~h} 00)$ on 8 or 10 levels. All the chlorophyll profiles had the same pattern, with a maximum always situated near $50 \mathrm{~m}$ depth. In contrast, the concentrations of chlorophyll showed very important diel variations at every depth; minimal values were observed at $2 \mathrm{~h} 00$ in the upper $40 \mathrm{~m}$, and at $8 \mathrm{~h} 00$ at 60 and $80 \mathrm{~m}$. Maximal values were always obtained at $14 \mathrm{~h} 00$. The average chlorophyll content of the euphotic layer was $22 \mathrm{mg} \cdot \mathrm{m}^{-2}$ at $2 \mathrm{~h} 00$ and 31 at $14 \mathrm{~h} 00$. Data were numerous and regular enough to allow calculation of the average concentration of chlorophyll for each sampling level and each sampling time for the 13-day study, as well as average increase and decrease of chlorophyll for each time period (differences which are for the most part statistically highly significant). Results are compared to the changes of chlorophyll measured every day in natural sea-water samples incubated in situ from sunrise to sunset : the chlorophyll content increased in the bottles by about $50 \%$ at $50 \mathrm{~m}$, and 150-200 \% between 20 and $30 \mathrm{~m}$. From this, and from in situ ${ }^{14} \mathrm{C}$ uptake measurements and several deck experiments, it is suggested that the observed diel variations of chlorophyll $a$ would result from the lag between two major processes having inverse effects : daytime chlorophyll synthesis in parallel to photosynthesis on one hand, continuous phytoplankton consumption by herbivorous zooplankton on the other hand. Schematically, chlorophyll changes would represent diel variations of the phytoplankton biomass itself.

Oceanol. Acta, 1982, 5, 4, 433-441.

\section{RÉSUMÉ}

Variation nycthémérale de la chlorophylle $a$ mise en évidence à partir d'une station fixe de 13 jours dans l'Atlantique équatorial.

Au cours de 13 jours d'étude en point fixe en Atlantique équatorial, la distribution verticale de la chlorophylle $a$ a été déterminée par fluorimétrie sur extraits acétoniques quatre fois par jour $(2 \mathrm{~h} 00,8 \mathrm{~h} 00,14 \mathrm{~h} 00$ et $20 \mathrm{~h} 00)$ sur 8 ou 10 niveaux. Les profils de chlorophylle ont une allure très régulière, avec un maximum toujours situé près de $50 \mathrm{~m}$. A l'inverse, les concentrations de chlorophylle présentent de très importantes variations nycthémérales à toutes les profondeurs. Les valeurs minimales sont observées à $2 \mathrm{~h}$ dans les 40 premiers mètres, et à $8 \mathrm{~h}$ à 60 et $80 \mathrm{~m}$. Les valeurs maximales sont toujours obtenues à $14 \mathrm{~h}$. Les données sont suffisamment nombreuses et régulières pour permettre le calcul de la concentration moyenne de chlorophylle sur 13 jours pour chaque niveau et chaque heure d'échantillonnage, de même que des augmentations ou baisses moyennes de chlorophylle pour chaque intervalle de temps (différences le plus souvent statistiquement hautement significatives). Le contenu moyen de chlorophylle de la couche euphotique est de $22 \mathrm{mg} \cdot \mathrm{m}^{-2}$ à 2 h 00 et 31 à 14 h 00 .

Ces résultats sont comparés aux variations de chlorophylle mesurées chaque jour dans des échantillons d'eau de mer incubés in situ du lever au coucher du soleil : le contenu en chlorophylle des bouteilles augmente d'environ $50 \%$ à $50 \mathrm{~m}$, et de 150 à $200 \%$ entre 20 et $30 \mathrm{~m}$. A partir de ces résultats et de mesures de fixation de ${ }^{14} \mathrm{C}$ in situ et de 
diverses expériences sur le pont, il est suggéré que les variations nycthémérales observées de la chlorophylle $a$ résulteraient du décalage entre deux processus majeurs ayant des effets inverses : synthèse de chlorophylle pendant le jour en parallèle avec la photosynthèse d'une part, consommation continue de phytoplancton par le zooplancton herbivore d'autre part. Schématiquement, les variations de chlorophylle représenteraient des variations nycthémérales de la biomasse phytoplanctonique elle-même.

Oceanol. Acta, 1982, 5, 4, 433-441.

\section{INTRODUCTION}

Numerous field studies have produced evidence of diel variations of chlorophyll $a$ in the sea (see reviews of Forsbergh, 1969 and Sournia, 1974). According to the periodicity exhibited by concentrations of chlorophyll $a$, different explanations have been advanced to account for the observations. Bleaching by light excess is often the cause of a decrease of chlorophll values during the day (Yentsch, Ryther, 1957; Ichimura, 1960; Glooschenko et al., 1972). Diel variations may be due to simple changes of the chlorophyll cell content resulting from a rhythm in the chlorophyll synthesis and accumulation (Glooschenko et al., 1972; Riper et al., 1979; Owens et al., 1980). They may represent net changes of the actual phytoplankton biomass, related with a periodicity of zooplankton feeding on phytoplankton, as suggested by Mc Allister (1963) and Wood and Corcoran (1966). These different explanations have quite different ecological significance, and this may modify the interpretation of chlorophyll data collected at any time during descriptive cruises.

In order to investigate the main causes of diel chlorophyll periodicity, field and shipboard experiments were performed with chlorophyll $a$ in the Gulf of Guinea. It appeared that above all, a good qualitative and quantitative description of the pigment variations was necessary (Ichimura, 1960; Angot, Gérard, 1966; Forsbergh, 1969; Glooschenko et al., 1972). In this respect one of the biggest problems encountered by investigators in the neritic or oceanic regions proceeds from sampling : how is it possible to obtain at regular intervals a number of samples representative of the time evolution of a single natural community of phytoplankton? If sampling takes place in a fixed geographic position, the physical and chemical structure may obviously change with time, because water flows under this point. It is known, moreover, that the vertical distribution and concentration of chlorophyll are mainly influenced by hydrological structure, and specially by depth and gradient of the thermocline and nitracline (Venrick et al., 1978; Herbland, Voituriez, 1979; Cullen, Eppley, 1981).

To solve this problem, we have studied the chlorophyll variations in a relatively stable hydrological structure, so that the physical and chemical properties of the water in the euphotic layer changed very little during the study. In addition, our field measurements and experiments were repeated for thirteen successive days, which permitted the elimination of extraneous causes of change, such as variations in the environment pro- perties, and allowed us to consider that the average variations of chlorophyll for one night-day cycle are those of a single phytoplanktonic community, considered as a whole.

\section{METHODS}

The « Cap 7912 » cruise of the RV Capricorne was in two parts : a thirteen-day study in a fixed position on the Equator in the Gulf of Guinea $\left(0^{\circ}-4{ }^{\circ} \mathrm{W}\right)$ from 20 October to 1 November, 1979 , and a transect at $4^{\circ} \mathrm{W}$ from $5^{\circ} \mathrm{N}$ to $5^{\circ} \mathrm{S}$ (from 5 to 9 November, 1979). For physical and chemical descriptions of the area, see respectively Voituriez (1981) and Oudot (1982).

For chlorophyll $a$ analysis, the same procedure was applied rigorously to all samples. The rosette sampler bottles coupled with the Bisset-Berman STDO probe system was used to sample on 8 fixed levels at $2 \mathrm{~h} 00$ and $14 \mathrm{~h} 00$ (U.T.) from 5 to $80 \mathrm{~m}$ depth, and on 10 fixed levels at $8 \mathrm{~h} 00$ and $20 \mathrm{~h} 00$, from 0 to $100 \mathrm{~m}$. Each $180 \mathrm{ml}$ sample was immediately filtered (depression about $10 \mathrm{mb}$ ) through a Whatman GF/C filter ( $\varnothing 25 \mathrm{~mm}$ ), ground and extracted in $90 \%$ acetone for at least $2 \mathrm{~h}$ in a refrigerator. Samples were then analyzed on a fluorometer Turner model 111 (Yentsch, Menzel, 1963) calibrated with pure chlorophyll $a$ (Sigma) by spectrophotometric measurement. Precision is given by analysis of 12 replicates of a natural phytoplankton sample : $\mathrm{cv}=4.8 \%$ for $\mathrm{m}=0.262 \mathrm{mg} \cdot \mathrm{m}^{-3}$.

Water for primary production was sampled before sunrise with a 301 Niskin PVC bottle at 8 levels. Nutrients $\left(\mathrm{NO}_{3}, \mathrm{NO}_{2}, \mathrm{NH}_{4}, \mathrm{PO}_{4}\right)$ were immediately analyzed with a Technicon autoanalyzer (Strickland, Parsons, 1972). Seawater for production measurements was filtered through a $200 \mu \mathrm{m}$ mesh net and incubated in situ from sunrise to sunset (mean duration : $11 \mathrm{~h}$ ) :

- $14 \mathrm{C}-\mathrm{CO}_{2}$ uptake in $300 \mathrm{ml}$ bottles (SteemannNielsen, 1952). Radio-activity was counted with a liquid scintillation counter;

- chlorophyll synthesis in 61 bottles also used for nitrate uptake measurement ( 4 samples by day). In each bottle, chlorophyll concentration is measured at the beginning and the end of daytime. The effect of ${ }^{15} \mathrm{~N}$ $\mathrm{NO}_{3}$ enrichment (from 0.9 to 1.7 mgat ${ }^{15} \mathrm{~N} . \mathrm{m}^{-3}$ ) on the chlorophyll synthesis was tested on different cultures of natural phytoplankton communities (Le Bouteiller, Herbland, 1982). For 5 and 9 h simulated in situ incubations, chlorophyll concentration increased in all cases. Enrichment influenced on chlorophyll accumulation only when water was nitrate-depleted. During the 
cruise, 52 samples were incubated in situ for nitrate uptake and chlorophyll synthesis measurements. Only 8 contained less than 0.2 mgat $-\mathrm{m}^{-3}\left(\mathrm{NO}_{3}^{-}\right)$, and their effect on the average values used below was neglected.

Light penetration in the water was measured every day at about $13 \mathrm{~h} 00$ with a Lambda quantameter, and incident radiation was recorded from a pyranometer Kipp and Zonen.

For statistical analysis, the non parametric test of Wilcoxon, as described by Siegel (1956), was used.

\section{RESULTS}

During the 13-day study, the vertical profiles of chlorophyll always showed the same pattern, with a weak maximum located near $50 \mathrm{~m}$ depth, coupled with a weak vertical gradient of temperature and nitrate (Fig. 1 and 2). Physical, chemical and biological properties showed only little change from day to day, with, however, a surface layer cooler and richer in nitrate and chlorophyll from 23 to 30 October, probably due to the meandering of the equatorial currents system (Herbland, Le Bouteiller, $1982 a$ ). Data showed no evidence of diel change in temperature, salinity, current or nutrients.

Chlorophyll maximum was always observed at $14 \mathrm{~h} 00$ at every level from 0 to $80 \mathrm{~m}$ (Fig. 3). This is in good

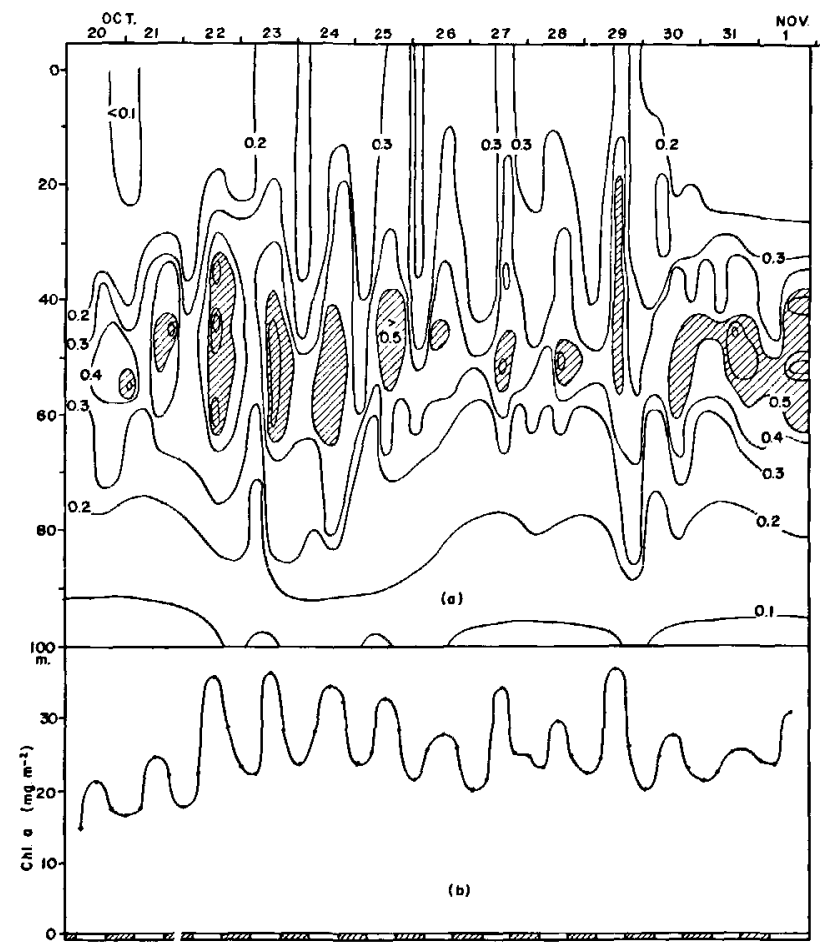

Figure 1

a) time course of change in concentration of chlorophyll a (mg. $\left.\mathrm{m}^{-3}\right)$ vs. depth, at one fixed position occupied during 13 days $\left(0^{\circ} ; 4^{\circ} \mathrm{W}\right)$, October 1979. 50 series of measurements at $2 \mathrm{~h} 00,8 \mathrm{~h} \mathrm{00,14 \textrm {h } 0 0}$ and $20 \mathrm{~h} 00$ (U.T.).

b) time evolution of the chlorophyll a integrated over $80 \mathrm{~m}$.

a) évolution dans le temps de la concentration de chlorophylle $a$ (mg. $\mathrm{m}^{-3}$ ) en fonction de la profondeur, à une station fixe occupée pendant 13 jours $\left(0^{\circ} ; 4^{\circ} \mathrm{W}\right)$, octobre 1979.50 séries de mesures à 2 h 00,8 h 00,14 h 00 et 20 h 00 (U.T.).

b) évolution dans le temps des valeurs intégrées de chlorophylle $a$ sur $80 \mathrm{~m}$.

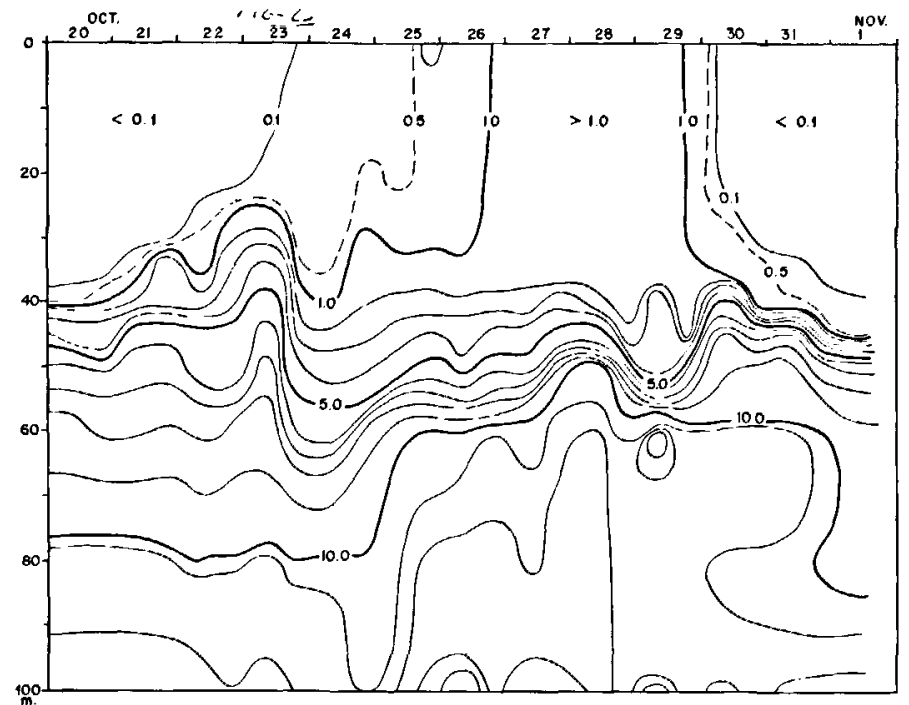

Figure 2

Time course of change in concentration of nitrate $\left(\right.$ mgat. $\left.\mathrm{m}^{-3}\right)$ vs. depth, during the 13 days study $\left(0^{\circ} ; 4^{\circ} \mathrm{W}\right) .25$ series of 10 measurements at $8 \mathrm{~h} 00$ and $20 \mathrm{~h} 00$ (U.T.).

Temperature distribution is very similar, since $\left(\mathrm{NO}_{3}\right)=-1.349 \mathrm{~T}$ $\left({ }^{\circ} \mathrm{C}\right)+33.59$ (calculated with $\mathrm{NO}_{3}>0.5$ mgat. $\mathrm{m}^{-3}, n=184$, $r=-0.977)$.

Evolution dans le temps des teneurs en nitrate $\left(\right.$ matg. $\left.\mathrm{m}^{-3}\right)$ en fonction de la profondeur au cours des 13 jours d'étude $\left(0^{\circ} ; 4^{\circ} \mathrm{W}\right) .25$ séries de 10 mesures à 8 h 00 et 20 h 00 (U.T.).

La distribution des températures est très semblable, puisque l'on a $\left(\mathrm{NO}_{3}\right)=-1,349 \mathrm{~T}\left({ }^{\circ} \mathrm{C}\right)+33,59$ (calculé avec $\mathrm{NO}_{3}>0,5$ mgat $\left.. \mathrm{m}^{-3}, \mathrm{n}=184, \mathrm{r}=-0,977\right)$.

agreement with the field observations of Ryther et al. (1961), Lorenzen (1963), and Wood and Corcoran (1966) in the Gulf of Guinea, but is in opposition to those of Yentsch and Scagel (1958), El-Sayed and Mandelli (1965), Glooschenko (1970), Glooschenko et al. (1972).

There was no surface measurement at $14 \mathrm{~h} 00$. However, from surface data at $8 \mathrm{~h} 00$ and $20 \mathrm{~h} 00$ and from the general pattern of the vertical profiles at $14 \mathrm{~h} 00$, surface chlorophyll would appear to be also maximal at $14 \mathrm{~h} 00$. Chlorophyll bleaching by light excess, suggested by several authors (Yentsch, Ryther, 1957; Shimada, 1958; Ichimura, 1960; Glooschenko et al., 1972) as the explanation of decreases of surface chlorophyll near midday, would be dominated here by other processes, such as chlorophyll synthesis or vertical mixing (Harris, 1973). In a 30-day nearshore study, Angot and Gérard (1966) observed a chlorophyll maximum at the surface, occurring near midday on the average. Forsbergh (1969) showed a similar midday chlorophyll maximum in the Panama Bight (476 data collected during one year). From continuous in vivo fluorescence measurement at $9.5 \mathrm{~m}$ depth during 11 days reported by Owens et al. (1980), chlorophyll content was maximal from 12 to $18 \mathrm{~h}$.

Minimal values were observed at $2 \mathrm{~h} 00$ in the surface layer, and at $8 \mathrm{~h} 00$ at 60 and $80 \mathrm{~m}$. Figures $3 a$ and 4 show that the chlorophyll minimum appears to shift in time from $2 \mathrm{~h} 00$ to $8 \mathrm{~h} 00 \mathrm{~h}$ between the surface and 80 $\mathrm{m}$. Concentrations of chlorophyll at $20 \mathrm{~h} 00$ were lower than those at $14 \mathrm{~h} 00$ at every depth; those at $2 \mathrm{~h} 00$ 

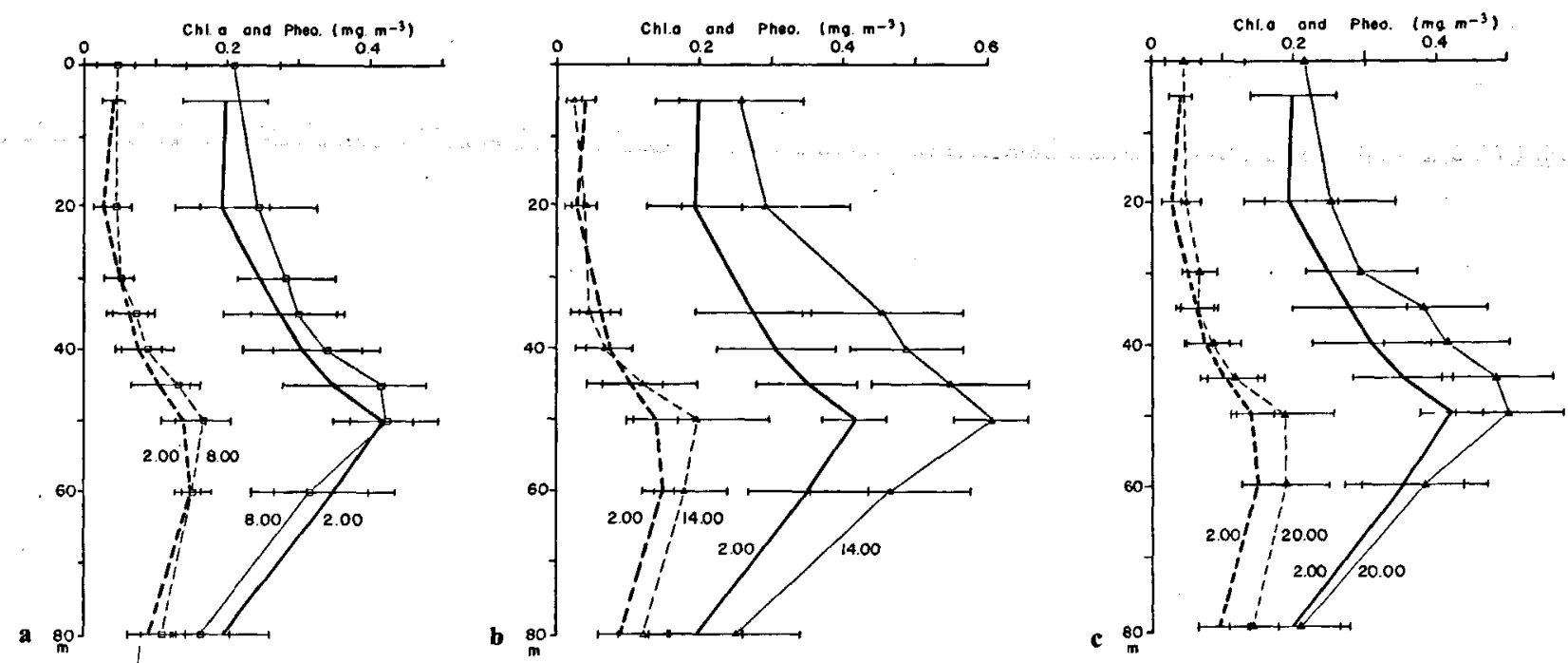

Figure 3

Depth distribution of chlorophyll a (solide lines) and pheophytin (dashed lines) (mean values over 13 days \pm standard deviation), a :

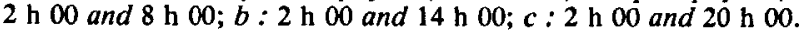

Distribution en fonction de la profondeur de la chlorophylle $a$ (traits continus) et de la phéophytine (traits discontinus) (moyennes \pm sd). a : 2 h 00 et 8 h 00; b : 2 h 00 et 14 h $00 ; c: 2$ h 00 et 20 h 00 .
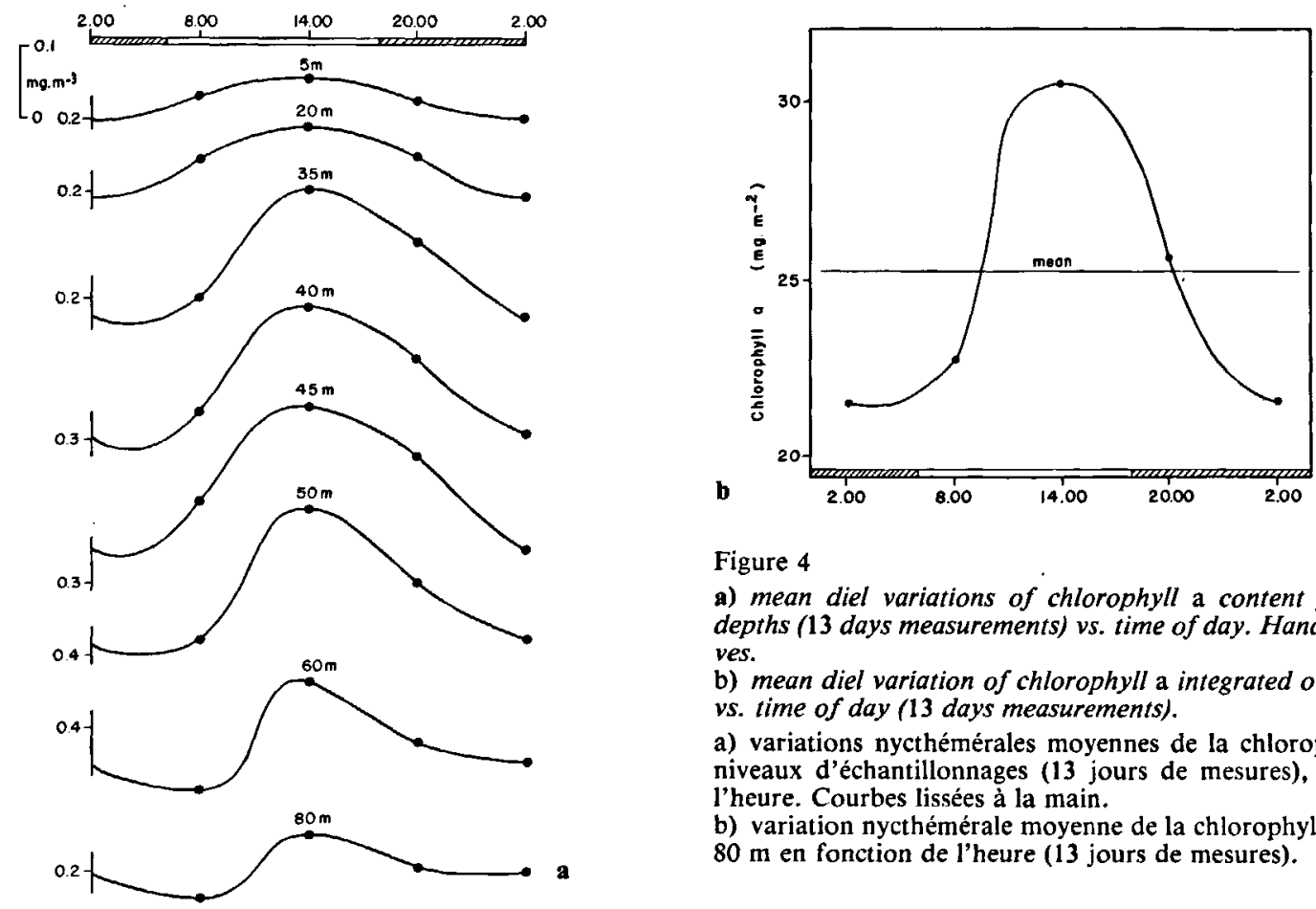

Figure 4

a) mean diel variations of chlorophyll a content for 8 sampling depths (13 days measurements) vs. time of day. Hand-smoothed curves.

b) mean diel variation of chlorophyll a integrated over $80 \mathrm{~m}$ depth, vs. time of day (13 days measurements).

a) variations nycthémérales moyennes de la chlorophylle $a$ pour 8 niveaux d'échantillonnages (13 jours de mesures), en fonction de l'heure. Courbes lissées à la main.

b) variation nycthémérale moyenne de la chlorophylle $a$ intégrée sur $80 \mathrm{~m}$ en fonction de l'heure (13 jours de mesures).

Table 1

Means of differences for chlorophyll a concentrations between two sampling times for each sampling depth ( $p=$ significance level of the differences for the non parametric Wilcoxon test. N.S. : no significant).

Moyennes des différences de teneur en chlorophylle $a$ entre deux heures d'échantillonnage pour chaque niveau de prélèvement $(p=$ niveau de significativité des différences pour le test non paramétrique de Wilcoxon. N.S. : non significatif).

\begin{tabular}{|c|c|c|c|c|c|c|c|c|c|c|c|c|c|c|c|}
\hline \multirow[b]{2}{*}{ depth } & \multicolumn{3}{|c|}{ from 2 h 00 to 8 h 00} & \multicolumn{3}{|c|}{ from 8 h 00 to 14 h 00} & \multicolumn{3}{|c|}{ from $14 \mathrm{~h} 00$ to $20 \mathrm{~h} 00$} & \multicolumn{3}{|c|}{ from $20 \mathrm{~h} 00$ to $2 \mathrm{~h} 00$} & \multicolumn{3}{|c|}{ from $2 \mathrm{~h} 00$ to $14 \mathrm{~h} 00$} \\
\hline & $\mathrm{mg} \cdot \mathrm{m}^{-3}$ & $\%$ & $\mathbf{P}$ & $\mathrm{mg} \cdot \mathrm{m}^{-3}$ & $\%$ & $\mathbf{P}$ & $\mathrm{mg} \cdot \mathrm{m}^{-3}$ & $\%$ & $\mathbf{P}$ & $\mathrm{mg} \cdot \mathrm{m}^{-3}$ & $\%$ & $\mathbf{P}$ & $\mathrm{mg} \cdot \mathrm{m}^{-3}$ & $\%$ & $\mathbf{P}$ \\
\hline $\begin{array}{l}0 \\
5\end{array}$ & +0.028 & +18.9 & 0.02 & \multirow{2}{*}{$\begin{array}{l}+0.016 \\
+0.034\end{array}$} & & & -0.031 & -15.1 & 0.05 & \multirow{2}{*}{$\begin{array}{l}-0.016 \\
-0.038\end{array}$} & & & \multirow{2}{*}{$\begin{array}{l}+0.053 \\
+0.098\end{array}$} & \multirow{2}{*}{$\begin{array}{r}+34.2 \\
+52.9\end{array}$} & 0.05 \\
\hline $\begin{array}{l}20 \\
30\end{array}$ & $\begin{array}{l}+0.060 \\
+0.057\end{array}$ & $\begin{array}{l}+32.1 \\
+29.0\end{array}$ & $\begin{array}{l}0.01 \\
0.01\end{array}$ & & +14.0 & 0.0 & $\begin{array}{l}-0.051 \\
-0.016\end{array}$ & $\begin{array}{l}-15.7 \\
-24.1\end{array}$ & $\begin{array}{l}0.05 \\
0.01\end{array}$ & & -14.0 & 0.02 & & & 0.01 \\
\hline 35 & +0.048 & +28.0 & 0.05 & +0.152 & +52.3 & 0.01 & -0.070 & -13.3 & 0.05 & -0.114 & -27.5 & 0.01 & \multirow{2}{*}{$\begin{array}{l}+0.198 \\
+0.199\end{array}$} & +87.5 & 0.01 \\
\hline 40 & +0.054 & +25.1 & 0.02 & +0 . & +46.6 & 0.0 & -0.061 & -10.6 & 0.0 & & -25.6 & & & & \\
\hline 45 & +0.063 & +21.1 & 0.01 & +0.152 & +40.4 & 0.01 & -0.065 & -8.7 & N.S. & -0.130 & -25.2 & 0. & \multirow{2}{*}{$\begin{array}{l}+0.222 \\
+0.174\end{array}$} & +67.9 & 0.01 \\
\hline 50 & +0.011 & $\begin{array}{r}+3.9 \\
\end{array}$ & N.S. & +0.159 & +44.3 & 0.01 & -0.069 & -11.5 & 0.01 & -0.085 & -15.4 & 0.01 & & + & 0.01 \\
\hline 60 & -0.031 & -7.3 & N.S. & +0.144 & +50.7 & 0.01 & -0.078 & -14.8 & 0.05 & -0.026 & -5.0 & N.S. & +0.110 & +35.6 & 0.02 \\
\hline 80 & -0.022 & -6.8 & N.S. & +0.068 & +39.9 & 0.01 & -0.040 & -13.1 & N.S. & -0.021 & -3.7 & N.S. & +0.053 & +30.0 & N.S. \\
\hline$\sum$ & & & & & & & & .3 & & & 5.0 & & & & 0.01 \\
\hline
\end{tabular}


Table 2

Changes of chlorophyll a concentration at $40 \mathrm{~m}$ between measurements in field at $6 \mathrm{~h}$ and at $10 \mathrm{~h}$ (U.T.).

Changements de la teneur en chlorophylle $a$ à $40 \mathrm{~m}$ entre les mesures dans le milieu à $6 \mathrm{~h}$ et à $10 \mathrm{~h}$ (T.U.).

\begin{tabular}{|c|c|c|c|c|c|c|c|c|c|c|}
\hline $\begin{array}{l}\text { Chlorophyll a } \\
\left(\mathrm{mg}^{-3}\right) \\
\text { increase }(\%)\end{array}$ & $\begin{array}{r}6 h \\
10 h\end{array}$ & $\begin{array}{l}0.75 \\
0.85 \\
+13\end{array}$ & $\begin{array}{l}0.91 \\
1.16 \\
+27\end{array}$ & $\begin{array}{r}0.98 \\
1.38 \\
+41\end{array}$ & $\begin{array}{l}0.98 \\
1.14 \\
+16\end{array}$ & $\begin{array}{l}0.95 \\
1.08 \\
+14\end{array}$ & $\begin{array}{r}0.65 \\
0.97 \\
+49\end{array}$ & $\begin{array}{r}0.53 \\
0.64 \\
+21\end{array}$ & $\begin{array}{l}0.26 \\
0.53 \\
+104\end{array}$ & $\begin{array}{l}0.28 \\
0.33 \\
+18\end{array}$ \\
\hline
\end{tabular}

Table 3

Changes of chlorophyll a content of the 0-100 m layer between measurements in field at $8 \mathrm{~h} 30$ and at $15 \mathrm{~h} 00$ (U.T.).

Changements du contenu en chlorophylle $a$ de la couche 0-100 m entre mesures dans le milieu à $8 \mathrm{~h} 30$ et à $15 \mathrm{~h} 00$ (T.U.).

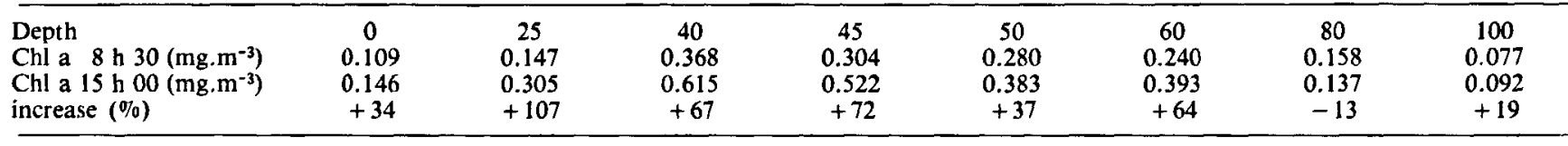

were also always lower than at $20 \mathrm{~h} 00$. No significant variation of pheophytin concentration appeared. The pheophytin rates (pheo)/pheo + Chl) accordingly showed inverse and symmetric variations in comparison with those of chlorophyll (Fig. 3).

To study the amplitude of variations we consider only arithmetic means estimated over 13 days (Table 1), which provide a good picture of the mean reality by eliminating analysis and sampling fluctuations and those due to variations of the environment, as noted by Platt (1972). Figure 4 shows the diel evolution of the chlorophyll content of a " mean " natural community of phytoplankton. Amplitude of variations increased from surface to $35 \mathrm{~m}$, and then decreased with depth. Chlorophyll concentration integrated over $80 \mathrm{~m}$ depth increased between $2 \mathrm{~h} 00$ and $14 \mathrm{~h} 00$ by $46,5 \%$ on average (Fig. $4 \mathrm{~b}$ ). Amplitudes of variation are lower than those reviewed by Forsbergh (1969). Our samples were collected at fixed times : consequently minimal and maximal values could be slightly under - or over - estimated, according to the actual time of passage of the chlorophyll through minimum and maximum for each depth level. On the other hand a number of amplitudes cited by Forsbergh (1969) were obtained from only one $24 \mathrm{~h}$ cycle, and hence could have been overestimed if the phytoplankton assemblages were not in ecological balance : any increase or decrease of the population during the $24 \mathrm{~h}$ observation period leads to an overestimation of the mere diel variation range of chlorophyll. On the other hand, when study was carried over several successive days, the amplitude of variations is very consistent with our own results. Thus, calculation from surface data collected by Angot and Gérard (1966) gives a mean increase of $74 \%$ ( $\mathrm{cv}=63 \%$ ) between $6 \mathrm{~h} 00$ and $12 \mathrm{~h} 00$ over 30 successive days $\left(\mathrm{m}=0,5 \mathrm{mg} \cdot \mathrm{m}^{-3}\right.$ chlorophyll).

Among the environmental factors which could influence the diel changes of chlorophyll, light and nitrate concentration are to be considered. Day-to-day variations of the incident radiation were very low during the 13-day study (average radiation $=2350$; minimum $=1540 ;$ maximum $\left.=2860 \mathrm{~J} \cdot \mathrm{cm}^{-2} \cdot \mathrm{day}^{-1}\right)$. Chlorophyll periodicity seems not to have been affected by these fluctuations. Depth of the euphotic layer was very constant (from 56 to $66 \mathrm{~m}$ for $1 \%$ light).

Variations of the natural nitrate concentration did not involve significant changes in the diel variations of chlorophyll. From 23 to 30 October (Fig. 2), nitrate was present in the surface mixed layer, but the amplitude of chlorophyll fluctuations was then maximal at 30 or $35 \mathrm{~m}$, at exactly the same level as when surface water was nitrate-depleted.

Other measurements of diel variations of chlorophyll concentrations in the equatorial Atlantic Ocean confirm the above data. During the " Cap 7903 " cruise in February 1979, at the same position $\left[0^{\circ}-4^{\circ} \mathrm{W}\right.$, (Herbland, Le Bouteiller, $1982 \mathrm{~b}$ )] increases of natural chlorophyll (analyzed by the same method) were measured for nine successive days by sampling at $40 \mathrm{~m}$ at $6 \mathrm{~h}$ and $10 \mathrm{~h}$ (Table 2).

Another similar result was obtained at the same position in January, 1980 ( « Cap 8001 " cruise) with two successive profiles from 0 to $100 \mathrm{~m}$ (Table 3).

During the second part of the «Cap 7912 » cruise, the depth distribution of chlorophyll concentration along the transect at $4^{\circ} \mathrm{W}$ (Fig. 5) show fluctuations of the chlorophyll amounts which may be explained not only by differences in the hydrological structure and nitrate concentration, but also by the diel variations of the chlorophyll content itself : the lowest values are found when sampling occurred during the night, and the highest during the day.

\section{DISCUSSION}

Among the various factors which regulate the chlorophyll amount measured at one given time and place, which are the most important? Any niajor methodological artefact may be excluded, since water was always sampled with the same system, analyzed with the same procedure, in the same time-limit, and, with certain exceptions, by the same operator. Any bias introduced by microscale distribution or random errors tend to be cancelled out by average or integration calculations. Variations of the hydrological structure, mixing, internal waves or oscillations of the Lomonosov equatorial under-current, might modify observations extending for only a few hours or a few days, but not over a period of 13 successive days, a fortiori when the physical and chemical structure is as steady as it was during the cruise (see Fig. 2).

Phytoplankton vertical migrations (Halse, 1950; Smayda, 1970; Sournia, 1974) were not directly 


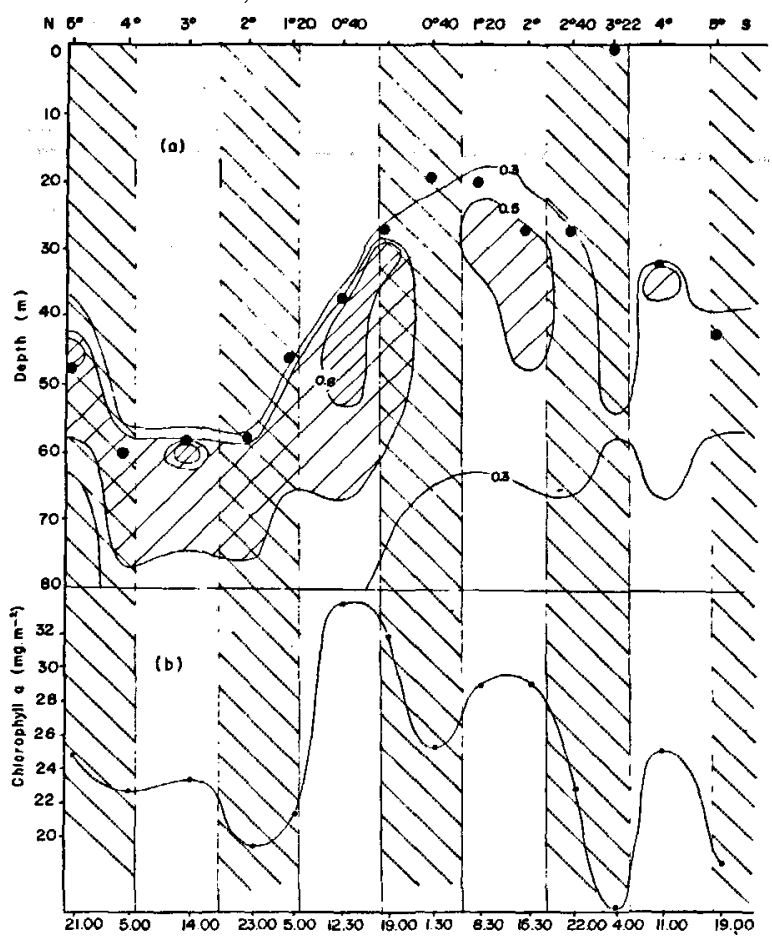

Figure 5

a) depth distribution of chlorophyll a concentration (mg. $\left.\mathrm{m}^{-3}\right)$ vs. latitude. Transect $\mathrm{N}-\mathrm{S}$ at $4^{\circ} \mathrm{W}$ during the second part of " Cap 7912 " cruise.

Full circles: depth of nitrate apparition.

b) chlorophyll a concentration integrated over $80 \mathrm{~m}$ depth, vs. time sampling (U.T.).

a) distribution de la chlorophylle $a\left(\mathrm{mg} \cdot \mathrm{m}^{-3}\right)$ en fonction de la latitude. Radiale N-S à $4^{\circ} \mathrm{W}$ au cours de la $2^{\mathrm{e}}$ partie de la campagne «Cap 7912 ".

Points noirs : niveau d'apparition du nitrate.

b) chlorophylle intégrée sur $80 \mathrm{~m}$ en fonction de l'heure.

measured. The early increase of chlorophyll in the surface layer may be attributed to upward migrations of phytoplankton, and the late increase under $50 \mathrm{~m}$ to a sinking movement (Fig. 4 a). However, the mean depth of chlorophyll maximum remains consistently at $50 \mathrm{~m}$ for all the 63 stations of chlorophyll measurement (Fig. 3), so that active or passive vertical displacements, if thus exist, would be dominated by other processes, in contrast with the observations reported by Dandonneau (1977) in the Dome of Angola.

Nor were cell number directly measured. We only know that cells were very little on average in the region concerned (Herbland, Le Bouteiller, 1981). Sournia (1974) and Harris (1978) concluded that the cell division of natural population of phytoplankton is synchronized at least to some extent, and that the general trend of algae is to divide at night. In the absence of a cell count, we can only suppose from the observation of chlorophyll maximum near midday and minimum at night that the synthesis and accumulation of chlorophyll processes are not synchronized with cell division rhythm; if they were, chlorophyll cell content would show periodic changes. This was evidenced by Hunter and Laws (1981) from continuous cultures :

The fact that cell quotas of chlorophyll $a$ tend to increase during the day and decrease at night is undoubtedly partly because cultures divide mainly in the dark. But Owens et al. (1980), with an asynchroneous culture of $S$. costatum, showed that cellular chlorophyll $a$ and $c$ content is also strongly coupled with the light/dark cycle and in that case, this does not result from cell division. Grumbach et al. (1978) and Riper et al. (1979) reported that the turnover time of the chlorophyll $a$ pool was very much shorter than the generation time of the phytoplankton. These observations suggest that planktonic algae are able to adapt their internal pool of chlorophyll very quickly to rapid changes of available light. Nevertheless, a clear indication of a dark loss of the chlorophyll cell content is rarely obtained from field measurements.

\section{Natural populations incubated in the dark}

10 duplicate samples were collected between 0 and $100 \mathrm{~m}$ at $8 \mathrm{~h} \mathrm{00}$, and filtered through a $200 \mu \mathrm{m}$ mesh net. Some were immediately analyzed for chlorophyll determination, and others after $6 \mathrm{~h}$ incubation in the dark (Tabie 4). Chlorophyll decreased by $3 \%$ on the average, but the difference is not statistically significant (Wilcoxon test).

Several other similar experiments performed on water sampled in the same region at different times of the day and incubated for 6 or $12 \mathrm{~h}$, led to the same conclusion : chlorophyll concentration remained much the same in the sample when prefiltered and incubated for 6 or $12 \mathrm{~h}$ in the dark. If chlorophyll synthesis does proceed at night (Riper et al., 1979), it does not seem to accumulate in the present conditions, which is in contrast with previous observations on exponentially growing populations (Yentsch, 1965; Eppley et al., 1971; Glooschenko et al., 1972). Furthermore, chlorophyll was not destroyed in the dark by catabolism or grazing : zooplankton was removed by pre-filtration, and the herbivorous species smaller than $200 \mu \mathrm{m}$ would be inhibited by the physiological stress due to sampling, screening or confinement in bottles, as observed by Venrick et al. (1977). Different opposite processes may of course cancel each other, with the result that chlorophyll synthesis just equals degradation. In the absence of better knowledge on the structure of the phototrophic and heterotrophic communities enclosed in the bottles and their behaviour and interaction during incubation, we shall consider, as the most plausible hypothesis, that in samples pre-filtered and incubated in dark, chlorophyll synthesis - like grazing - is negligible.

Table 4

Changes of chlorophyll a content in flasks incubated in the dark between $8 \mathrm{~h} 00$ and $14 \mathrm{~h} 00$.

Changements du contenu en chlorophylle $a$ dans les flacons incubés dans le noir entre $8 \mathrm{~h} 00$ et $14 \mathrm{~h} 00$.

\begin{tabular}{lcccccccccc}
\hline Depth & 0 & 20 & 30 & 35 & 40 & 45 & 50 & 60 & 80 & 100 \\
Chl a 8 h o0 (mg.m -3 $\left.^{-3}\right)$ & 0.292 & 0.309 & 0.317 & 0.283 & 0.306 & 0.449 & 0.335 & 0.262 & 0.159 & 0.081 \\
Chl a 14 h 00 (mg.m m $\left.^{-3}\right)$ & 0.280 & 0.309 & 0.319 & 0.282 & 0.329 & 0.437 & 0.298 & 0.216 & 0.155 & 0.082 \\
increase (\%) & -4 & 0 & +1 & 0 & +8 & -3 & -11 & -18 & -3 & +1 \\
\hline
\end{tabular}




\section{Fied populations during the night}

Between 20 h 00 and $2 \mathrm{~h} 00$, the sole period entirely in the dark, chlorophyll standing stock systematically declined at every sampling depth (Fig. 3 c). Differences are very often highly significant (Table 1). These decreases of chlorophyll at night may be compared with the above incubations in the dark, performed on the same populations of phytoplankton. If there is neither marked synthesis of chlorophyll in the dark nor degradation by catabolism, we may conclude that under field conditions, grazing by zooplankton would be the main cause of chlorophyll decrease by night.

\section{Natural populations incubated in situ during the day}

In the 61 bottles incubated in situ from sunrise to sunset, chlorophyll concentration increased by 50-150\% (Table 5). These samples were screened in the same manner as those incubated in the dark (see above). The only difference between these two sets of experiments was available light : in one case, light was available and an abundant synthesis of chlorophyll occurred; in the other, there was neither light nor a marked net change of chlorophyll. In addition, accumulations of chlorophyll in samples incubated in situ during the day were much higher than those estimated in field at the same stations (see Fig. 4 and Table 1 : maximum increase between 8 h 00 and 14 h $00:+52 \%$ ). This enhancement of the accumulation of chlorophyll in the prefiltered samples supports the above hypothesis: screening removes from bottles, or inhibits, a major part of the predators, as suggested by Sheldon et al. (1973). On the contrary, in field, phytoplankton was

\section{Table 5}

1) Chlorophyll a accumulated in samples screened on $200 \mu \mathrm{m}$ net and incubated in situ from sunrise to sunset. Mean values, standard deviations and sample numbers.

2) ${ }^{14} \mathrm{C}$ uptake in samples incubated in the same conditions as those for chlorophyll synthesis measurements. Mean values.

3) Chlorophyll a loss per day, calculated by multiplying by 4 the dark loss of chlorophyll concentration measured in field between $20 \mathrm{~h} 00$ and $2 \mathrm{~h} 00$.

Mean values over 13 days of measurement.

1) Chlorophylle $a$ accumulée dans les échantillons tamisés sur filet de $200 \mu \mathrm{m}$ et incubés in situ du lever au coucher du soleil. Valeurs moyennes, déviations standard et nombres d'échantillons.

2) Fixation de ${ }^{14} \mathrm{C}$ dans les échantillons prélevés et incubés dans les mêmes conditions que pour les mesures de synthèse de chlorophylle. Valeurs moyennes.

3) Perte par jour de chlorophylle $a$ calculée en multipliant par 4 la perte nocturne de chlorophylle mesurée dans le milieu entre $20 \mathrm{~h} 00 \mathrm{et}$ $2 \mathrm{~h} 00$ du matin.

Valeurs moyennes sur 13 jours de mesures.

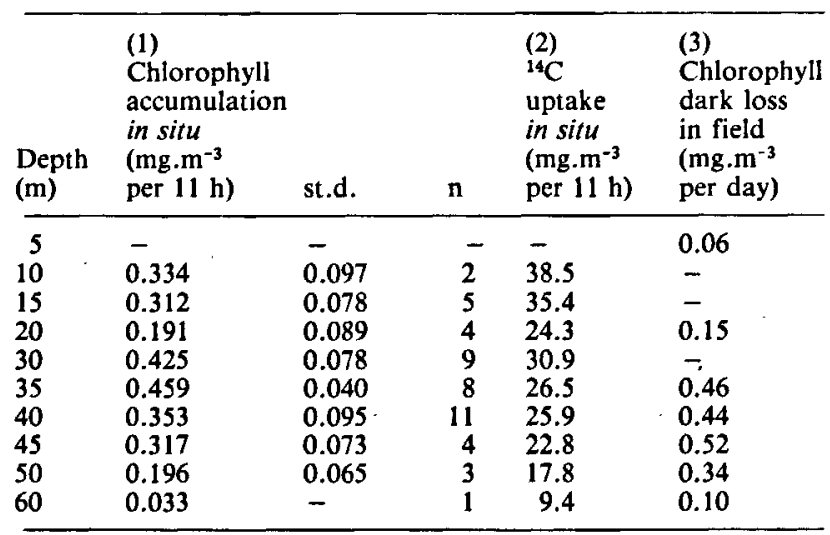

continuously consumed by heterotrophs, and the chlorophyll variation range was consequently much lower than chlorophyll changes in bottles incubated in situ.

Thus, 1) if we consider that decreases of chlorophyll assessed in field between $20 \mathrm{~h} 00$ and $2 \mathrm{~h} 00$ were mainly due to consumption by zooplankton, and are equivalent to a measure of grazing rate; 2 ) if we assume moreover that such a grazing rate represents a fairly good value of the average grazing rate by day, we may then multiply by 4 the amounts of chlorophyll loss between $20 \mathrm{~h} 00$ and $2 \mathrm{~h} 00$ to obtain an estimate of the total loss by day, which is equivalent to the net primary production. This calculation, very approximate indeed, is however possible since the system was in quasi steady-state conditions : the average standing stock by day was almost constant throughout the 13 days of study (Fig. 1). The values obtained in this manner are remarkably close to those provided by in situ incubations (Table 5), even if so many are possible sources of discrepancy, such as grazing diel rhythm (Mc Allister, 1971; Boucher et al., 1975; Hayward, 1980; Boyd et al., 1980). However, this similarity suggests that the production of chlorophyll in the pre-filtered samples during the day-time balanced losses by zooplankton predation over a $24 \mathrm{~h}$ period. Growth rates calculated for photoperiod from chlorophyll synthesis in the bottles are about 2.1-2.4 day $^{-1}$ for the layer $20-30 \mathrm{~m}$, and $1.0 \mathrm{day}^{-1}$ at $50 \mathrm{~m}$ (Le Bouteiller, Herbland, 1982).

From the pattern outlined in Figures 1 and 4, it is evident that chlorophyll concentration was closely coupled with light periodicity. Light/dark period was near $12 / 12 \mathrm{~h}$ and sun culminated at $12 \mathrm{~h} 16$ (U.T.) at the station position. Chlorophyll content in the euphotic layer was maximal near $14 \mathrm{~h}$. The apparent increase rate of chlorophyll, represented on Figure 4 by the positive slope of each smooth curve, passed through a maximum between 8 and $12 \mathrm{~h}$.

Photosynthetic capacity is also wellknown for its marked diel rhythm (Doty, Oguri, 1957), showing a maximum either in mid-morning or in mid-afternoon (Malone, 1971); photosynthetic carbon fixation, on the other hand, parallels the circadian solar radiation. Comparison of ${ }^{14} \mathrm{C}$ uptake data with chlorophyll increase data (Table 5) shows that these processes are both of the expected order of magnitude. Hence, photosynthesis and chlorophyll accumulation would be two processes occurring mainly during daylight in the equatorial ecosystem. Smayda (1975) monitored the diel cycles dealing with phytoplankton in field : elementary composition and chlorophyll content, photosynthesis and nutrients uptake, chlorophyll synthesis, excretion, cell division, vertical migration. Carbohydrate and protein content also has a rhythm, increasing during the photophase and decreasing at night (Hitchcock, 1980). The same is true for ATP (Hunter, Laws, 1981). However, knowledge about the synchronism between all these diel periodicities is relatively poor. Schematically, photosynthesis, nutrients uptake, enzymatic activity, carbohydrate, protein, ATP and chlorophyll synthesis all seem to occur mainly between sunrise and sunset.

From these considerations, and from our data, it is sug- 
gested that, for a phytoplankton population isolated from zooplankton predation :

- during the day, growth rate of standing stock and chlorophyll synthesis are high and pass through a maximum;

- if cells divide rather little, then cell size (Eppley, Coastworth, 1966; Staley, 1971) and cellular chlorophyll content increase in the day-time (as observed by J $\not r g e n s e n, ~ 1966 ;$ Riper et al., 1979; Owens et al., 1980; Hunter, Laws, 1981);

- inversely, by night, growth rate and chlorophyll synthesis are low, biomass varies little, and chlorophyll cell content probably declines because of cell divisions.

If the synthesis of chlorophyll and growth of standing stock are both periodical processes nearly in phase, then for a given light level in the euphotic zone, the (chlorophyll)/(biomass) ratio may be expected to vary very little during the day/night cycle. This implies that diel variations of the chlorophyll concentration in field reflect variations of the phytoplankton biomass.

\section{CONCLUSIONS}

Our observations provide clear evidence of systematic diel variations of chlorophyll. They support the hypothesis that these variations are representative of the time evolution of the phytoplankton biomass. Chlorophyll fluctuations would result from the cumulative effects of the chlorophyll synthesis in parallel with photosynthesis and a continuous consumption by herbivorous zooplankton. It is likely that such marked diel variations of chlorophyll occur only when environmental conditions are particularly stable, and when chlorophyll is relatively abundant. The tropical marine ecosystem allowed to meet these conditions : thermocline and nitracline depths were almost fixed, mixed layer was shallow, depth of euphotic zone and incident radiation were quasi constant. Under such conditions, equilibrium is established between the different compartments of the marine food chain, so that almost the entire day-time primary production is consumed by heterotrophs during a period of $24 \mathrm{~h}$. The rhythm imposed by solar irradiance on photosynthesis has consequences not only for the rhythm of chlorophyll synthesis, but also for the changes of standing stock. Then, measurements in detail of the diel variations of chlorophyll may be used for estimating growth rate of a natural phytoplankton community in ecological balance. This method presents the major advantage of not introducing any methodological artefact (sampling, screening, bottle confinement, etc.) : it considers the time evolution of the natural phytoplankton assemblages in their own environment.

Our results suggest that :

- diel variations of chlorophyll $a$ can be very important in the studied region, and deserve further investigation, especially during descriptive cruises with sampling at any time of the day;

- the equatorial Atlantic region is an highly dynamic ecosystem, with phytoplankton growth rate much higher than expected from the observed relatively low concentrations of chlorophyll.

\section{Aknowledgements}

The authors wish to thank Mr. Michel Skubich for his active participation in the many sampling operations and analyses carried out during the cruise.

\section{REFERENCES}

Angot M., Gérard D., 1966. Hydrologie et phytoplancton de l'eau de surface en avril 1965 à Nosy-Bé, Cah. ORSTOM, sér. Océanogr.; 4, 95-136.

Boucher J., Laurec A., Samain J.F., Smith S.L., 1975. Étude de la nutrition, du régime et du rythme alimentaire du zooplancton dans les conditions naturelles, par la mesure des activités enzymatiques digestives, in : 1Oth Europ. Symp. Mar. Biol., Ostend, Belgium, Vol. 2, 85-110.

Boyd C.M., Smith S.L., Cowles T.J., 1980. Grazing patterns of copepods in the upwelling system off Pern, Limnol. Oceanogr., 25, 583-596.

Cullen J.J., Eppley R.W., 1981. Chlorophyll maximum layers of the Southern California Bight and possible mechanisms of their formation and maintenance, Oceanol. Acta, 4, 1, 23-32.

Dandonneau Y., 1977. Variations nycthémérales de la profondeur du maximum de chlorophylle dans le dôme d'Angola (février-mars 1971), Cah. ORSTOM, sér. Océanogr., 15, 27-37.

Denman K.L., 1977. Short term variability in vertical chlorophyll structure, Limnol. Oceanogr., 22, 434-441.

Doty M.S., Oguri M., 1957. Evidence for a photosynthesis daily periodicity, Limnol. Oceanogr., 2, 37-40.

El-Sayed S.Z., Mandelli E.F., 1965. Primary production and standing crop of phytoplankton in the Weddel Sea and Drake Passage, in : Biology of the Antarctic Seas. Vol. 2, edited by G.A. Lalno, American Geophysics Union, Publication 1297, Washington, D.C., 87-106.

Eppley R.W., Coatsworth J.L., 1966. Culture of the marine phytoplankton Dunaliella tertiolecta, with light-dark cycles, Arch. Mikrobiol., 55, 66-80.
Eppley R.W., Carlucci A.F., Holm-Hansen O., Kieffer D., Mc Carthy J.J., Venrick E., Williams P.M., 1971. Phytoplankton growth and composition in shipboard cultures supplied with nitrate, ammonium, or urea as the nitrogen source, Limnol. Oceanogr., 16, 741-751.

Eppley R.W., Sapienza C., Renger E.H., 1978. Gradients in phytoplankton stocks and nutrients off Southern California in 1974-1976, Estuarine Coastal Mar. Sci., 7, 291-301.

Forsbergh E.D., 1969. On the climatology, oceanography and fisheries of the Panama Bight, Inter. Am. Trop. Tuna Comm. Bull., 14, 45-385.

Glooschenko W.A., 1970. Diel periodicity of chlorophyll $a$ in the Gulf of Mexico, Quart. J. Fla. Acad. Sci., 33, 786-799.

Glooschenko W.A., Curl H. Jr., Small L.F., 1972. Diel periodicity of chlorophyll a concentration in Oregon coastal waters, J. Fish. Res. Board Can., 29, 1253-1259.

Grumbach K.H., Lichtenthaler H.K., Erismann K.H., 1978. Incorporation of ${ }^{14} \mathrm{CO}_{2}$ in photosynthetic pigments of Chlorella pyrenoidosa, Planta, 140, 37-43.

Harris G.P., 1973. Vertical mixing mechanisms and their effects on primary production of phytoplankton, Sci. Ser. $\mathrm{N}^{\circ} 33$, Burlington, Ontario, Inland Waters Directorate, Canada Cent. Inland Waters, $17 \mathrm{p}$.

Harris G.P., 1978. Photosynthesis, productivity and growth : the physiological ecology of phytoplankton, Arch. Hydrobiol., 10, 1-171.

Hasle G.R., 1950. Phototactic vertical migrations in marine dinoflagellates, Oikos, 2, 162-175. 
Hayward T.L., 1980. Spatial and temporal feeding patterns of copepods from the North Pacific central gyre, Mar. Biol., 58, 292-310.

Herbland A., Voituriez B., 1979. Hydrological structure analysis for estimating the primary production in the Tropical Atlantic Ocean, J. Mar. Res., 37, 87-101.

Herbland A., Le Bouteiller A., 1981. The size distribution of phytoplankton and particulate organic matter in the Equatorial Atlantic Ocean : importance of ultraseston and consequences, J. Plankton Res., 3, 659-673.

Herbland A., Le Bouteiller A., $1982 a$. Dynamique du phytoplancton et matière organique particulaire dans la zone euphotique de l'Atlantique équatorial, Mar Biol., in press.

Herbland A., Le Bouteiller A., $1982 b$. The meanders of equatorial current : influence on the biological processes, Oceanogr. Trop., in press.

Hitchcock G.L., 1980. Diel variation in chlorophyll $a$, carbohydrate and protein content of the marine diatom Skeletonema costatum, Mar. Biol., 57, 271-278.

Hunter B.L., Laws E.A., 1981. ATP and chlorophyll $a$ as estimators of phytoplankton carbon biomass, Limnol. Oceanogr., 26, 944-956. Ichimura S., 1960. Diurnal fluctuation of chlorophyll content in lake water, Botanic. Mag., 73, 217-224.

Jorgensen E.G., 1966. Photosynthetic activity during the life cycle of synchronous Skeletonema cells, Physiol. Plant., 19, 789-799.

Le Bouteiller A., Herbland A., 1982. Synthèse de chlorophylle et production primaire : 13 jours de mesures in situ en un point fixe de l'Atlantique équatorial, Actualités de biochimie marine, Actes Colloq. CNEXO, Vol. 5, in press.

Lorenzen C.J., 1963. Diurnal variation in photosynthetic activity of natural phytoplankton populations, Limnol. Oceanogr., 8, 56-62.

Malone T.C., 1971. Diurnal rhythms in netplankton and nannoplankton assimilation ratios, Mar. Biol., 10, 285-289.

Me Allister C.D., 1963. Measurements of diurnal variation in productivity at ocean station « P ", Limnol. Occanogr., 8, 289-292.

Mc Allister C.D., 1971. Some aspects of nocturnal and continuous grazing by planktonic herbivores in relation to production studies, Fish. Res. Board. Can., Tech. Rep., 248, 1-281.

Oudot C., 1982. Distribution des sels nutritifs dans le Golfe de Guinée, Oceanogr. Trop., in press.

Owens T.G., Falkowski P.G., Whitledge T.E., 1980. Diel periodicity in cellular chlorophyll content in marine diatoms, Mar. Biol., 59, 71-77.

Platt T., 1972. Local phytoplankton abundance and turbulence, Deep-Sea Res., 19, 183-187.

Riper D.M., Owens T.G., Falkowski P.G., 1979. Chlorophyll turnover in Skeletonema costatum, a marine plankton diatom, Plant. Physiol. Lancaster, 64, 49-54.

Ryther J.H., Menzel D.W., Vaccaro R.F., 1961. Diurnal variations in some chemical and biological properties of the Sargasso Sea, Limnol. Oceanogr., 6, 149-153.
Sheldon R.W., Sutcliffe W.H. Jr., Prakash A., 1973. The production of particles in the surface water of the ocean with particular reference to the Sargasso Sea, Limnol. Oceanogr., 18, 719-731.

Shimada B.M., 1958. Diurnal fluctuation in photosynthetic rate and chlorophyll $a$ content of phytoplankton from eastern Pacific waters, Limnol. Oceanogr., 3, 336-339.

Siegel S., 1956. Nonparametric statistics for the behavioral sciences, International student edition, $312 \mathrm{p}$.

Smayda T.J., 1970. The suspension and sinking of phytoplankton in the sea, Oceanogr. Mar. Biol. Ann. Rev., 8, 353-414.

Smayda T.J., 1975. Phased cell division in natural populations of the marine diatom Ditylum brightwellii and the potential significance of diel phytoplankton behavior in the sea, Deep-Sea. Res., 22, 151-165.

Sournia A., 1974. Circadian periodicities in natural populations of marine phytoplankton, Adv. Mar. Biol., 12, 325-389.

Staley J.T., 1971. Growth rates of algae determined in situ using an immersed microscope, J. Phycol., 7, 13-18.

Steemann-Nielsen E., 1952. The use of radioactive carbon $\left({ }^{14} \mathrm{C}\right)$ for measuring organic production in the sea, J. Cons. Cons. Perm. Inter. Explor. Mer., 18, 117-140.

Strickland J.D.H., Parsons T.R., 1972. A practical handbook of seawater analysis, Bull. Fish. Res. Board Can., 167, 311 p.

Venrick E.L., Mac Gowan J.A., Mantyla A.W., 1973. Deep maxima of photosynthetic chlorophyll in the Pacific Ocean, Fish. Bull., 71, 41-52.

Venrick E.L., Beers J.R., Heinbokel J.F., 1977. Possible consequences of containing microplankton for physiological rate measurements, J. Exp. Mar. Biol. Ecol., 26, 55-76.

Voituriez B., Dandonneau Y., 1974. Relations entre la structure thermique, la production primaire et la régénération des sels nutritifs dans le Dôme de Guinée, Cah. ORSTOM, sér. Océanogr., 12, 241255.

Voituriez B., 1981. The equatorial upwelling in the Eastern Atlantic Ocean, SCOR WG 47 Meeting, Venice, 27-3 April 1981.

Wood E.J.F., Corcoran E.F., 1966. Diurnal variation in phytoplankton, Bull. Mar. Sci., 16, 383-403.

Yentsch C.S., 1965. Distribution of chlorophyll and phaeophytin in the open ocean, Deep-Sea Res. Oceanogr. Abstr., 12, 653-666.

Yentsch C.S., Ryther J.H., 1957. Short-term variations in phytoplankton chlorophyll and their significance, Limnol. Oceanogr., 2, 140-142.

Yentsch C.S., Scagel R.F., 1958. Diurnal study of phytoplankton pigments : an in situ study in East Sound, Washington, J. Mar. Res., 17, 567-583.

Yentsch C.S., Menzel D.W., 1963. A method for the determination of phytoplankton chlorophyll and phaeophytin by fluorescence, Deep-Sea Res., 10, 221-231. 